\title{
Seasonal Distribution of Micronutrients in Mature 'Concord' Grape: Boron, Iron, Manganese, Copper, and Zinc
}

\author{
Suphasuk Pradubsuk and Joan R. Davenport ${ }^{1}$ \\ Department of Crop and Soil Sciences, Washington State University, Irrigated Agriculture and \\ Research Extension Center, 24106 North Bunn Road, Prosser, WA 99350
}

\begin{abstract}
This study investigated the distribution of the micronutrients boron (B), iron (Fe), manganese (Mn), copper $(\mathrm{Cu})$, and zinc $(\mathrm{Zn})$ in 42-year-old 'Concord' grapevines (Vitis labruscana Bailey) grown in a calcareous soil to understand seasonal partitioning and distribution of micronutrients throughout various grapevine tissues. In 2006 and 2007, four vines each were excavated at winter pruning, budbreak, the three- to four-leaf stage, bloom, veraison, harvest, and postharvest. Separated plant organs were measured for biomass and analyzed for $\mathrm{B}, \mathrm{Fe}, \mathrm{Mn}, \mathrm{Cu}$, and $\mathrm{Zn}$. The results showed that seasonal patterns of micronutrient concentrations varied considerably with respect to organ and growth stage. Leaf blades, shoot tips, and petioles had the highest concentration of $B$ at bloom and Mn at harvest, whereas $\mathrm{Fe}, \mathrm{Cu}$, and $\mathrm{Zn}$ concentrations were highest in fine roots but values varied over time each year. Whereas seasonal patterns of $\mathrm{Fe}, \mathrm{Cu}$, and $\mathrm{Zn}$ contents differed year by year, $\mathrm{B}$ and $\mathrm{Mn}$ contents had a similar pattern over both years. Translocation of $B$ and $M n$ from woody tissue to actively growing organs occurred at the beginning of the season. The majority of $B$ uptake occurred between bloom and veraison, whereas that of Mn occurred between bloom and harvest. There were similar $B$ concentrations in shoot tips and leaf blades. Boron remobilization to woody tissues from the leaves occurred between veraison and harvest, suggesting moderate, late-season, phloem mobility of $B$ in 'Concord' grapevines. Microsite differences in soil $\mathrm{pH}$ likely contribute to variable nutrient availability around the root system, demonstrated by high variability of $\mathrm{Fe}, \mathrm{Cu}$, and $\mathrm{Zn}$ contents in different vine organs.
\end{abstract}

'Concord' grapevine is a cold climate juice grape originating in the New England region of the United States in naturally acidic soils (Brady and Weil, 1999). Currently, the majority of U.S. 'Concord' production is in Washington State (U.S. Department of Agriculture, 2008), where the predominantly calcareous and/or high $\mathrm{pH}$ soils could limit the availability of micronutrients, because they tend to precipitate out of soil solution in a carbonate-dominated environment (Epstein and Bloom, 2005). Micronutrient deficiencies have been shown to result in chronic chlorosis and subsequent yield loss in 'Concord' grape grown in calcareous soils when cold, wet soil conditions before bloom impede root growth and/or function (Davenport and Steven, 2006).

Although macronutrients are either involved structurally (proteins and nucleic acids) or elecrochemically (key cations involved in charge stabilization), micronutrients tend to function as catalysts in enzyme systems (Marschner, 2002). Nutrients are transported in the soil solution by either diffusion or mass flow (Brady and Weil, 1999). Mass flow generally satisfies B requirements of plants growing in most soils (Tinker and Nye, 2000), whereas transfer of $\mathrm{Zn}$ from the soil solution to the root surface occurs mainly by diffusion and is likely to occur very close to root hairs. Previous research reported that the diffusion

Received for publication 9 Sept. 2010. Accepted for publication 19 Oct. 2010. We gratefully acknowledge Washington State Concord Grape Research Council for funding support.

Special thanks to Richard Koenig and Donald Horneck for technical consultations as well as to Kelly Whitley, Jaimi Marden, and Kyle Bair for fieldwork support and technical assistance. We also thank the WSU-Prosser Viticulture team for vineyard maintenance.

This article is a portion of a dissertation submitted by Suphasuk Pradubsuk in fulfilling a $\mathrm{PhD}$ requirement.

${ }^{1}$ Corresponding author. E-mail: jdavenp@wsu.edu. coefficient of $\mathrm{Zn}$ in a calcareous loam was $\approx 50$-fold lower than that of an acidic soil (Melton et al., 1973). Meeting plant demand for $\mathrm{Cu}, \mathrm{Fe}, \mathrm{Mn}$, and $\mathrm{Zn}$ is challenging because they typically are found in low concentrations in the soil solution (Cass, 2005). Concentrations of $\mathrm{Mn}, \mathrm{Fe}, \mathrm{Zn}$, and $\mathrm{Cu}$ in the soil solution depend largely on the soil $\mathrm{pH}$, redox potential, and soil organic matter content, all of which will fluctuate throughout the season in temperate climates (Chesworth, 1991; Sinclair et al., 1990). In addition, $\mathrm{Fe}, \mathrm{Cu}, \mathrm{Zn}$, and $\mathrm{Mn}$ transport is often complicated by the chemical nature of these cations, which tend to form metalorganic complexes of varying stability, size, and charge (Tiffin, 1972).

Micronutrient availability generally decreased as the soil $\mathrm{pH}$ increased with the exception of molybdenum (Anderson and Christensen, 1988; Shuman, 1998). Increasing soil pH decreased the exchangeable fractions and increased the more tightly bound fractions of Zn (Iyengar et al., 1981), Cu (Sims, 1986) Fe (Daniels and Haering, 2006), and Mn (Loganathan et al., 1977). Bates et al. (2002) studied the effects of soil pH on young 'Concord' grapevines and reported no difference in vegetative growth of the 'Concord' vines grown in soil of $\mathrm{pH}$ ranging from 5.0 to 7.5. However, they reported a trend toward decreased shoot growth with an increased root:shoot ratio above a soil of $\mathrm{pH}$ above 7.0.

Compared with other crops, grapevines appear to have low root densities (Schreiner and Linderman, 2005; Smart and Coombe, 1983) but extensive lateral and vertical spread (Smart et al., 2005). Grape yield and quality are both dependent on root health (Morlat and Jacquet, 1993) with fine roots largely involved in water and nutrient uptake. The rate of nutrient uptake by the plant depends not only on the mobility of the nutrients in the soil, but also on having a well-distributed and functioning root system, which is, in turn, influenced by access through the soil solution to the plant nutrients required for growth. 
Nutrient recycling is key to grapevine nutrient supply. Within the vineyard, when no supplements are provided, nutrients are largely derived from leaf senescence and shredded debris that becomes available after decomposition (Mullins et al., 1992; Winkler et al., 1974). Harvested fruit represent a net nutrient loss as do nutrient losses resulting from leaching and runoff (Mullins et al., 1992; Winkler et al., 1974). Perennial tissues or woody structures are sources of nutrients at the beginning of the season and thus exhibit a demand for lateseason nutrient storage for the next season. Conversely, annual tissues (leaves, fruit, new roots) are the greatest determinant of vine nutrient demand. Nutrients contained in the annual tissues come from soil uptake and reserves translocated from permanent structures (Conradie, 1980, 2005).

Although research in grapevine nutrition has been conducted in several different growing regions, previous studies have focused on the uptake of nitrogen and other macronutrients in whole vines. Little research has been done on micronutrient distribution and uptake in grapevines. Schreiner et al. (2006) found that uptake for most macronutrients was very closely related to canopy demand, whereas concentrations of micronutrients $\mathrm{Fe}, \mathrm{Mn}, \mathrm{B}, \mathrm{Zn}$, and $\mathrm{Cu}$ in the whole vine varied considerably from vine to vine in Oregon 'Pinot Noir' wine grape (Vitis vinifera L.) and did not show clear seasonal trends. Colugnati et al. (1995) studied vine Fe, Mn, and B content in four different grape cultivars and found total B absorption increased continuously throughout the growing period, whereas total Fe and Mn content increased during the vegetative cycle, then remained steady before veraison, and then progressively increased from veraison to fruit maturity. However, direct comparison of wine grape and 'Concord' nutrient uptake and partitioning may not be possible as a result of differences in management strategies (e.g., pruning, thinning) as well as desired crop yield levels (typically less than $8 \mathrm{Mg} \cdot \mathrm{ha}^{-1}$ for wine grape and greater than $20 \mathrm{Mg} \cdot \mathrm{ha}^{-1}$ for 'Concord'). In addition, size and seasonal duration of vegetative, reproductive, and storage sinks might vary with vine age (Borchert, 1976), cultivars (Colugnati et al., 1995), and variable weather conditions (Robinson, 2005).

The goal of 'Concord' production is to produce the highest yielding mature fruit while maintaining vine performance. Balance of nutrients should be a high priority for vineyard management to accomplish this goal because there is a direct impact of plant growth and development on juice quality. This study was undertaken to investigate seasonal patterns of aboveground and below-ground biomass as well as micronutrient

Table 1. Weather condition and sampling date according to phenological development of 'Concord' grapes in a Yakima Valley, WA, vineyard in 2006 and 2007.

\begin{tabular}{|c|c|c|c|c|c|c|c|}
\hline \multirow[b]{2}{*}{ Growth stage } & \multicolumn{2}{|c|}{ Sampling date } & \multicolumn{2}{|c|}{ GDD greater than $10{ }^{\circ} \mathrm{C}^{\mathrm{z}}$} & \multicolumn{2}{|c|}{ Mean temp $\left({ }^{\circ} \mathrm{C}\right)^{\mathrm{z}}$} & \\
\hline & 2006 & 2007 & 2006 & 2007 & 2006 & 2007 & \\
\hline Dormant & 7 Mar. & 5 Mar. & - & - & 6.63 & 8.21 & March \\
\hline Budbreak & 3 Apr. & 2 Apr. & 52 & 41 & 10.79 & 10.08 & April \\
\hline \multirow[t]{2}{*}{ Bloom } & 6 June & 6 June & 278 & 246 & 18.79 & 17.43 & June \\
\hline & & & 430 & 466 & 23.27 & 23.54 & July \\
\hline Veraison & 26 Aug. & 10 Aug. & 336 & 318 & 20.84 & 20.30 & August \\
\hline Postharvest & 9 Oct. & 8 Oct. & 34 & 27 & 10.25 & 8.27 & October \\
\hline Cumulative GDD & & & 1503 & 1414 & & & \\
\hline
\end{tabular}

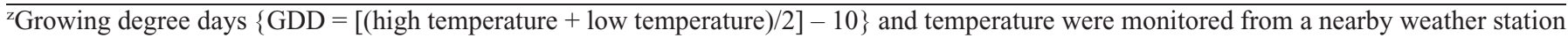
using data loggers (CR-1000; Campbell Scientific, Logan, UT).

${ }^{\mathrm{y}}$ Cumulative GDD between budbreak and harvest for each year.

Table 2. Relationships among dry weight, nutrient content and concentration, and grapevine growth stage, organs, and the interactive factor growth stage (GS) and organ (O) of 'Concord' grape in 2006 and 2007.

\begin{tabular}{|c|c|c|c|c|c|c|c|c|c|c|}
\hline \multirow{2}{*}{ Parameter } & \multicolumn{5}{|c|}{2006} & \multicolumn{5}{|c|}{2007} \\
\hline & \multicolumn{2}{|c|}{ Growth stage } & \multicolumn{2}{|c|}{ Organ } & $\frac{\mathrm{GS} \times \mathrm{O}}{P}$ & \multicolumn{2}{|c|}{ Growth stage } & \multicolumn{2}{|c|}{ Organ } & $\frac{\mathrm{GS} \times \mathrm{C}}{P}$ \\
\hline Dry wt & 0.0001 & 102.73 & 0.0001 & 111.4 & 0.0001 & 0.0001 & 100.57 & 0.0001 & 100.56 & 0.0001 \\
\hline Magnesium concn & 0.0001 & 0.016 & 0.0001 & 0.02 & 0.0001 & 0.0001 & 0.01 & 0.0001 & 0.01 & 0.0001 \\
\hline Boron content & 0.0001 & 1.32 & 0.0001 & 1.44 & 0.0001 & 0.0001 & 1.49 & 0.0001 & 1.62 & 0.0001 \\
\hline Iron content & 0.0001 & 19.32 & 0.0001 & 20.92 & 0.0001 & 0.0230 & 65.72 & 0.0001 & 48.80 & 0.1075 \\
\hline Copper content & 0.0001 & 0.61 & 0.0001 & 0.68 & 0.0001 & 0.0001 & 0.78 & 0.0001 & 0.84 & 0.0001 \\
\hline Zinc content & 0.0001 & 5.24 & 0.0001 & 5.49 & 0.0001 & 0.0001 & 4.51 & 0.0001 & 4.39 & 0.0001 \\
\hline Boron concn & 0.0001 & 1.03 & 0.0001 & 1.13 & 0.0001 & 0.0001 & 1.59 & 0.0001 & 1.72 & 0.0001 \\
\hline Iron concn & 0.0001 & 63.62 & 0.0001 & 69.27 & 0.0001 & 0.0001 & 93.79 & 0.0001 & 97.74 & 0.0001 \\
\hline Manganese concn & 0.0001 & 1.64 & 0.0001 & 1.81 & 0.0001 & 0.0001 & 2.43 & 0.0001 & 2.55 & 0.0001 \\
\hline Copper concn & 0.0001 & 1.32 & 0.0001 & 1.46 & 0.0001 & 0.0001 & 1.61 & 0.0001 & 1.75 & 0.0001 \\
\hline
\end{tabular}

$\mathrm{LSD}=$ least significant difference. 
uptake and redistribution in mature 'Concord' grapevines grown in a calcareous soil.

\section{Materials and Methods}

The study was conducted in an ownrooted 'Concord' single-curtain vineyard (lat. 46 $15^{\prime} 59^{\prime \prime} \mathrm{N}$, long. 119 $44^{\prime} 4^{\prime \prime} \mathrm{W}$ ) at the Irrigated Agriculture Research and Extension Center in Prosser, WA. Vines were planted in 1965 spaced with $1.83 \mathrm{~m}$ between plants and $3.05 \mathrm{~m}$ between rows. The site was furrow-irrigated and had been managed with uniform fertilization, water, and pest management practices for 40 years. The vineyard soil was a Warden fine sandy loam (coarse-silty, mixed, superactive, mesic Xeric Haplocambid). As a result of the great diversity in plant sizes in the vineyard, all grape plants in the 1.5 -acre vineyard were measured to determine uniform-sized vines for excavation. These criteria were 12.8- to $15.0-\mathrm{cm}$ trunk circumference at $30 \mathrm{~cm}$ above the soil surface, $87-$ to $99-\mathrm{cm}$ trunk length from soil surface to cordon split, and 25- to $36-\mathrm{cm}$ cordon length before attachment to the cordon wire.

In 2006 and 2007 at winter pruning, budbreak, three- to four-leaf stage, bloom, veraison, harvest, and postharvest (Table 1), all above-ground portions and a comparable below-ground portion $(2.4 \times 2.7 \times 1 \mathrm{~m})$ of four uniformly sized vines were destructively harvested. Each vine was separated into trunk and cordon, coarse roots (diameter greater than $4 \mathrm{~mm}$ ), fine roots (diameter less than $4 \mathrm{~mm}$ ), canes, shoot, leaf blades, petioles, shoot tips, and clusters (including rachis and seeds). Coarse roots and fine roots were washed through a 2-mm wet sieve to completely remove soil and were thoroughly rinsed twice with deionized water to remove any physical contaminants.

Separated plant tissues were dried $\left(70{ }^{\circ} \mathrm{C}\right.$, $48 \mathrm{~h}$ ), weighed, and finely ground to pass through a 40-mesh screen, except for the large woody pieces. For the large woody pieces such as the trunk, two small sections were collected. One was weighed and dried to determine dry weight, whereas the other was pre-ground moist in a coffee mill (Krups, Millville, NJ), then dried, and finely ground. Samples were digested with nitric acid and hydrogen peroxide in a microwave oven (CEM, Matthews, NC) and analyzed using an inductively coupled plasma spectrometer [ICP (Thermo Jarrell Ash, Franklin, MA)] (Soltanpour et al., 1996) for B, Fe, Mn, Cu, and $\mathrm{Zn}$ by a commercial laboratory. Surface $(0$ to $30 \mathrm{~cm})$ and subsurface $(30$ to $75 \mathrm{~cm})$ soil samples were collected at each harvest point and analyzed for the availability of the

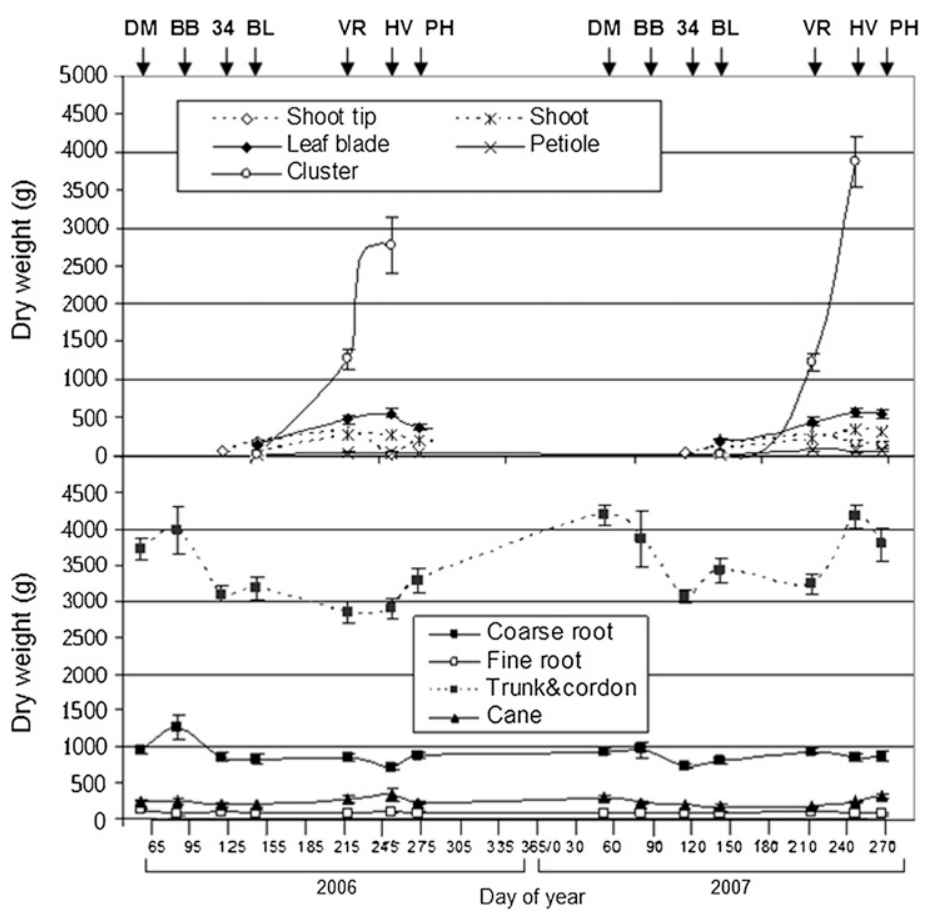

Fig. 1. Seasonal changes in dry mass of 'Concord' grape plant parts in a vineyard in the Yakima Valley, WA, in 2006 and 2007. Arrows at the top of graph indicate the time of dormant (DM), budbreak (BB), three- to four-leaf stage (34), bloom (BL), veraison (VR), harvest (HV), and postharvest (PH), Data points represent means with SE at each sampling date $(n=4)$.

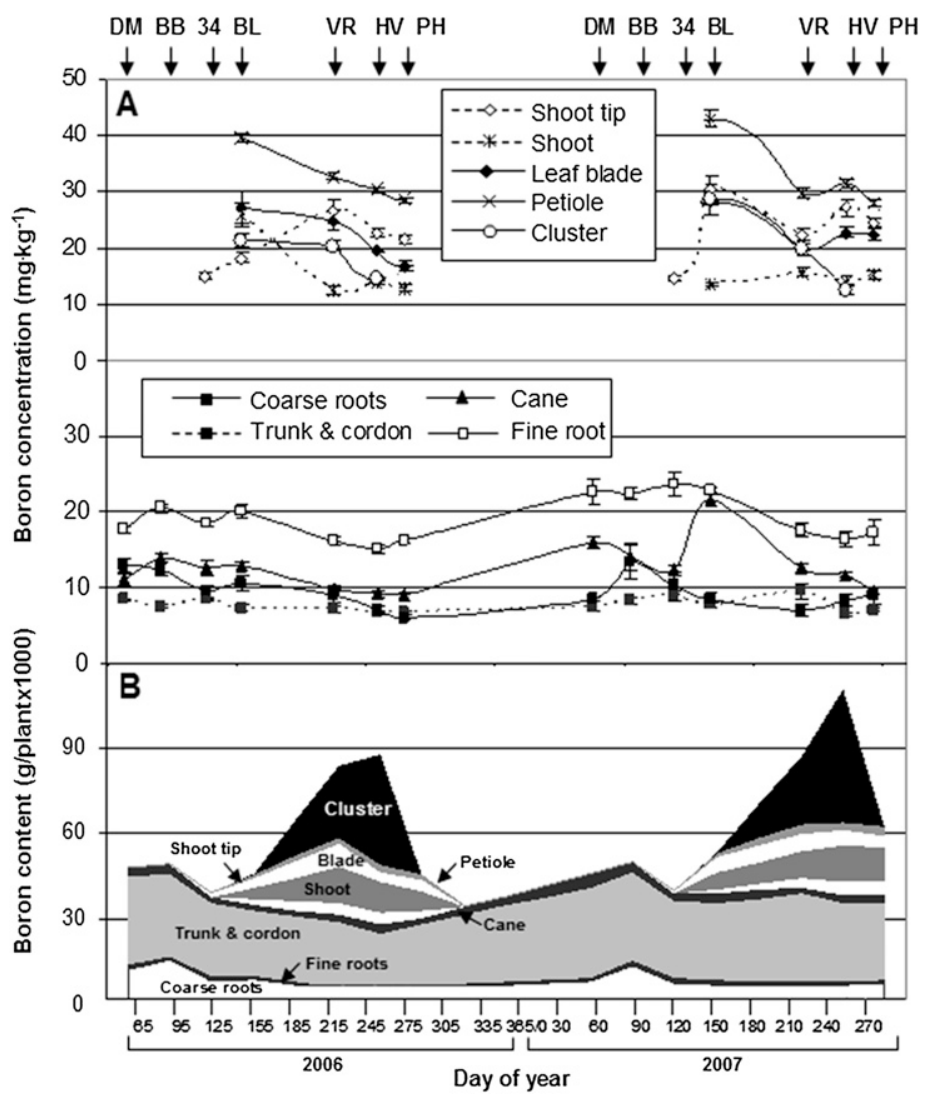

Fig. 2. Seasonal change in concentrations (A) and contents $(\mathbf{B})$ of boron in various organs of 'Concord' grape in 2006 and 2007. Arrows at the top of graph indicate the time of dormant (DM), budbreak (BB), three- to four-leaf stage (34), bloom (BL), veraison (VR), harvest (HV), and postharvest (PH). Data points represent means with SE at each sampling date $(n=4)$. 
elements listed by using a Mehlich III extraction (Mehlich, 1984) and ICP analysis.

Initial data analysis was conducted using Proc GLM of PC SAS (Version 9.2 for Windows; SAS Institute, Cary, NC) to evaluate the influence of the main and interactive effects on both tissue nutrient concentration (ICP values) and content [dry mass $\times$ concentration (Table 2)]. Additionally, nutrient content was analyzed relative to nutrient concentration, plant dry weight, and the interaction between concentration and dry weight. Although $\mathrm{B}$ and $\mathrm{Zn}$ were significantly correlated $(P<0.01), \mathrm{Cu}, \mathrm{Fe}$, and $\mathrm{Mn}$ were not $(P>0.05)$.

Data were subsequently analyzed using analysis of variance with SPSS (Version 15.0; SPSS, Chicago, IL) to examine changes in dry weight and nutrient concentrations of each micronutrient in all plant parts over time. Because dry weight was significantly different by year, data were analyzed separately for each year. Mean separation used least significant difference at $P<0.05$ level. Seasonal whole vine micronutrient contents were calculated (dry mass $\times$ concentration) and graphed. Net nutrient movement between various plant parts was demonstrated by dividing the calculated content of each micronutrient within each plant part by the number of days between sampling dates (Pradubsuk and Davenport, 2010).

\section{Results and Discussion}

The overall patterns of 'Concord' dry weight accumulation are reported in Pradubsuk and Davenport (2010). The patterns were similar over 2 years with the whole plant biomass at harvest approximately double that in winter, budbreak, three- to four-leaf stage, and bloom (Fig. 1). However, there were differences between 2006 and 2007 in woody tissue (trunk and cordon) dry weight between budbreak and the three- to four-leaf stage as well as cluster dry weight at harvest. The change in tissue dry weight was consistent with losses and gains in carbon (C) content, notwithstanding small variation of $\mathrm{C}$ concentrations ( $46 \%$ to $48 \%$ of dry weight) of various vine parts (Pradubsuk and Davenport, 2010). In addition, concentrations of $\mathrm{B}, \mathrm{Fe}, \mathrm{Mn}, \mathrm{Cu}$, and $\mathrm{Zn}$ in the clusters did not vary between years (Figs. 2-6).

Micronutrient CONCENTRATIONS IN VINE ORGANS. Changes in B concentrations of various vine parts were similar in 2006 and 2007 , except that shoot tip B concentrations increased significantly between bloom and veraison in 2006 but decreased during the same period in 2007 (Fig. 2). In both years, leaf blade and petiole $\mathrm{B}$ concentration decreased significantly between bloom and veraison, whereas fine root, coarse root, and cane B concentration increased after harvest, and trunk and cordon $\mathrm{B}$ concentration remained constant throughout the season. In this regard, lower B concentrations were found in petioles and clusters at bloom and in shoots at veraison in 2006 as compared with 2007.
Iron concentrations were highest and most dynamic in fine roots, petioles, leaf blades, and shoot tips (Fig. 3). However, there were no clear seasonal patterns of concentration changes in fine roots and petioles, whereas leaf blade and shoot tip Fe concentrations were the highest between veraison and harvest. Throughout the two growing seasons, Fe concentrations in trunk, cordon, coarse roots, canes, shoots, and clusters remained constant and were approximately two to four times lower than leaf blade and shoot tip concentrations and $\approx 10$ times lower than fine roots.

Manganese concentrations in permanent structures (trunk, cordons, and coarse roots) did not change over time, whereas cane Mn concentrations were high at the beginning of the season and gradually decreased at or after budbreak, reaching the lowest values between bloom and veraison with a slight increase at harvest (Fig. 4). In both years, shoot tip Mn concentrations significantly decreased from the three- to four-leaf stage to bloom and then significantly increased until the end of the season, which mirrored changes observed in leaf petioles and blades during the same period. Conversely, cluster Mn concentrations significantly declined after bloom, reaching the lowest values at veraison or harvest. With the exception of the fine roots, Mn concentration changes in the other organs were similar in both years with highest concentration found in leaf blade.

Compared with other organs, fine root $\mathrm{Cu}$ concentrations were highest and the most variable, especially at the beginning

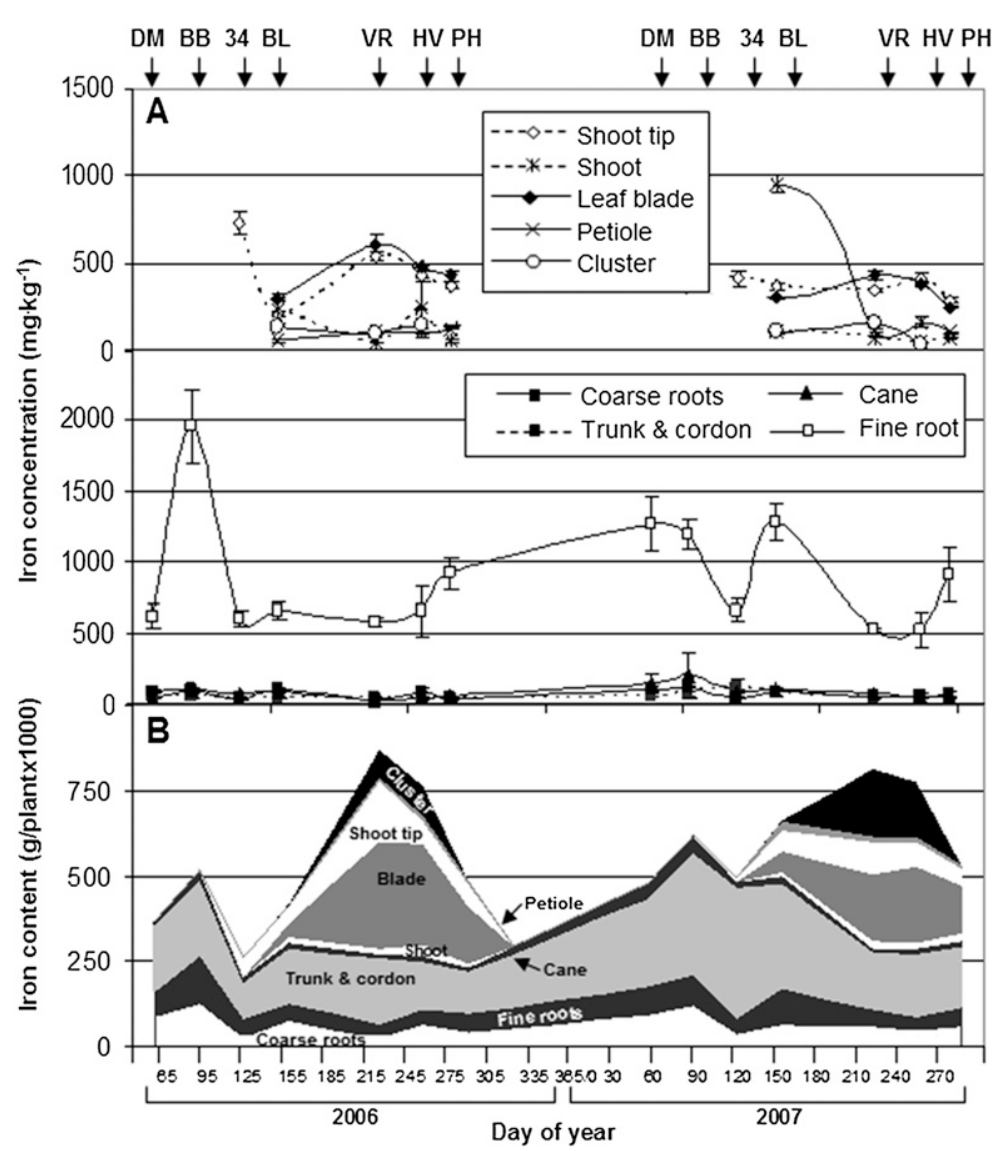

Fig. 3. Seasonal change in concentrations (A) and contents (B) of iron in various organs of 'Concord' grape in 2006 and 2007. Arrows at the top of graph indicate the time of dormant (DM), budbreak (BB), three- to four-leaf stage (34), bloom (BL), veraison (VR), harvest (HV), and postharvest (PH). Data points represent means with SE at each sampling date $(n=4)$. 


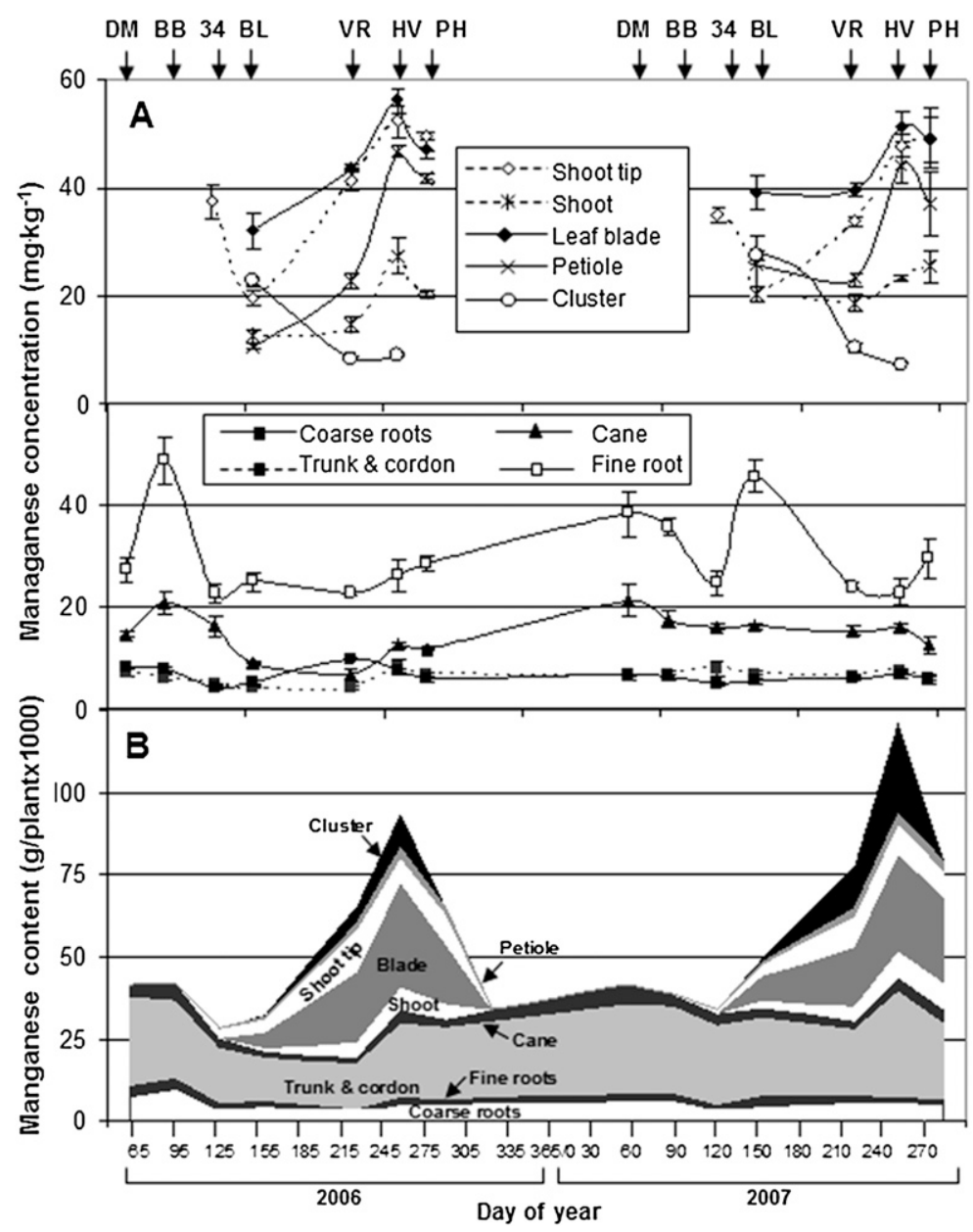

Fig. 4. Seasonal change in concentrations (A) and contents (B) of manganese in various organs of 'Concord' grape in 2006 and 2007. Arrows at the top of graph indicate the time of dormant (DM), budbreak (BB), three- to four-leaf stage (34), bloom (BL), veraison (VR), harvest (HV), and postharvest $(\mathrm{PH})$. Data points represent means with SE at each sampling date $(\mathrm{n}=4)$.

creased from the three- to four-leaf stage to harvest before gradually decreasing after harvest.

Seasonal partitioning of MicronuTRIENTS. From 1 year to the next, tissues in which the majority of changes in nutrient content occurred differed between nutrients. Almost half of the total $\mathrm{B}, \mathrm{Fe}, \mathrm{Mn}$, and $\mathrm{Cu}$ content was in leaf blades and clusters from veraison to harvest (Figs. 2-5, respectively), whereas up to $77 \%$ of the $\mathrm{Zn}$ was located in the trunk and cordon (Fig. 6), and $\approx 15 \%$ of $\mathrm{Fe}$ and $\mathrm{Cu}$ was found in fine roots throughout the growing season. The largest $\mathrm{Zn}$ content ( 80 to $110 \mathrm{mg}$ ) was found in trunks, consistent with Schreiner et al. (2006), who found that most of the $\mathrm{Zn}(\approx 99 \mathrm{mg})$ was located in vine trunks.

Schreiner et al. (2006) reported that the greatest content of $\mathrm{Fe}$ in 'Pinot Noir' wine grape was found in coarse and fine roots, whereas the highest Mn content was located in leaf blades and those of B and $\mathrm{Zn}$ were in the trunk. In our study, the total micronutrient content of the whole plant was consistent with whole plant total micronutrient content reported for 'Pinot Noir'. However, we found that the 'Concord' micronutrients were distributed differently throughout the vine when compared with 'Pinot Noir' (Schreiner et al., 2006). In 'Concord', the greatest $\mathrm{Cu}$ and $\mathrm{Mn}$ content were found in the trunk, whereas the highest $\mathrm{B}$ and $\mathrm{Fe}$ content were in both the leaf blade and trunk. These differences could be the result of differences in vine age and cultivar and/or site conditions such as soil characteristics and water availability, which impact both nutrient demand and storage

of the season when the concentrations were very high at budbreak in 2006 and at dormancy in 2007 (Fig. 5). In both years, trunk, cordon, coarse root, cane, and shoot $\mathrm{Cu}$ concentrations were lowest at the three- to four-leaf stage, whereas the highest $\mathrm{Cu}$ concentration was found in shoot tips at the three- to four-leaf stage as well as in leaf blades, petioles, and clusters at bloom. Copper concentrations in annual tissues significantly decreased from bloom to veraison and showed little change through the remainder of the season.

Zinc concentrations were highest and varied the most in fine roots, whereas $\mathrm{Zn}$ concentration in other organs was much lower throughout both growing seasons (Fig. 6). Although there was no clear fine root seasonal pattern, highest $\mathrm{Zn}$ concentrations were found at budbreak in 2006 and at bloom in 2007. In both years, $\mathrm{Zn}$ concentrations in the trunk, cordon, coarse roots, and canes at budbreak were slightly higher than at later growth stages through harvest. Zinc concentrations in shoot tips were highest at the three- to four-leaf stage and $\mathrm{Zn}$ in leaf blades and clusters were highest at bloom and then significantly decreased until the end of the season. However, shoot tip $\mathrm{Zn}$ concentrations in 2007 were significantly higher than in 2006, especially during the three- to four-leaf and bloom stages. In contrast to the other micronutrients, petiole $\mathrm{Zn}$ concentrations significantly in- reserves. Plants in both studies were own-rooted.

Examining whole vine total micronutrient content, seasonal changes in B and Mn were similar between 2006 and 2007 in terms of highest nutrient accumulation in the leaf blades and clusters during active vine growth (Figs. 2 and 4, respectively). Boron uptake (53\% to $90 \%$ of total) was highest from bloom to veraison, whereas the highest uptake of Mn ( $76 \%$ to $95 \%$ of total) occurred from bloom to harvest. Increased B content during this period is consistent with findings in which total B content of the entire plant increased throughout the season (Colugnati et al., 1995). Throughout the growing season, average total uptake per plant of B and Mn were 59 and $64 \mathrm{mg}$, respectively, in 2006 and in 200773 and $92 \mathrm{mg}$, respectively, were taken up. The greater uptake of both $\mathrm{B}$ and $\mathrm{Mn}$ in 2007 compared with 2006 corresponds to a higher cluster biomass in the 2007 (Fig. 1). Clusters at the time of harvest constituted $45 \%$ of the dry matter and up to $63 \%$ B was located in the soft (annual) tissues.

In both years, at the three- to four-leaf stage, there was a large reduction in $\mathrm{B}$ content in the coarse roots versus a slight decrease in the trunk and cordons, suggesting that more reserve $\mathrm{B}$ for new growth was translocated from coarse roots than from the trunk and cordon (Fig. 2). The combination of B concentration and the plant dry weight contributing to vine B content 


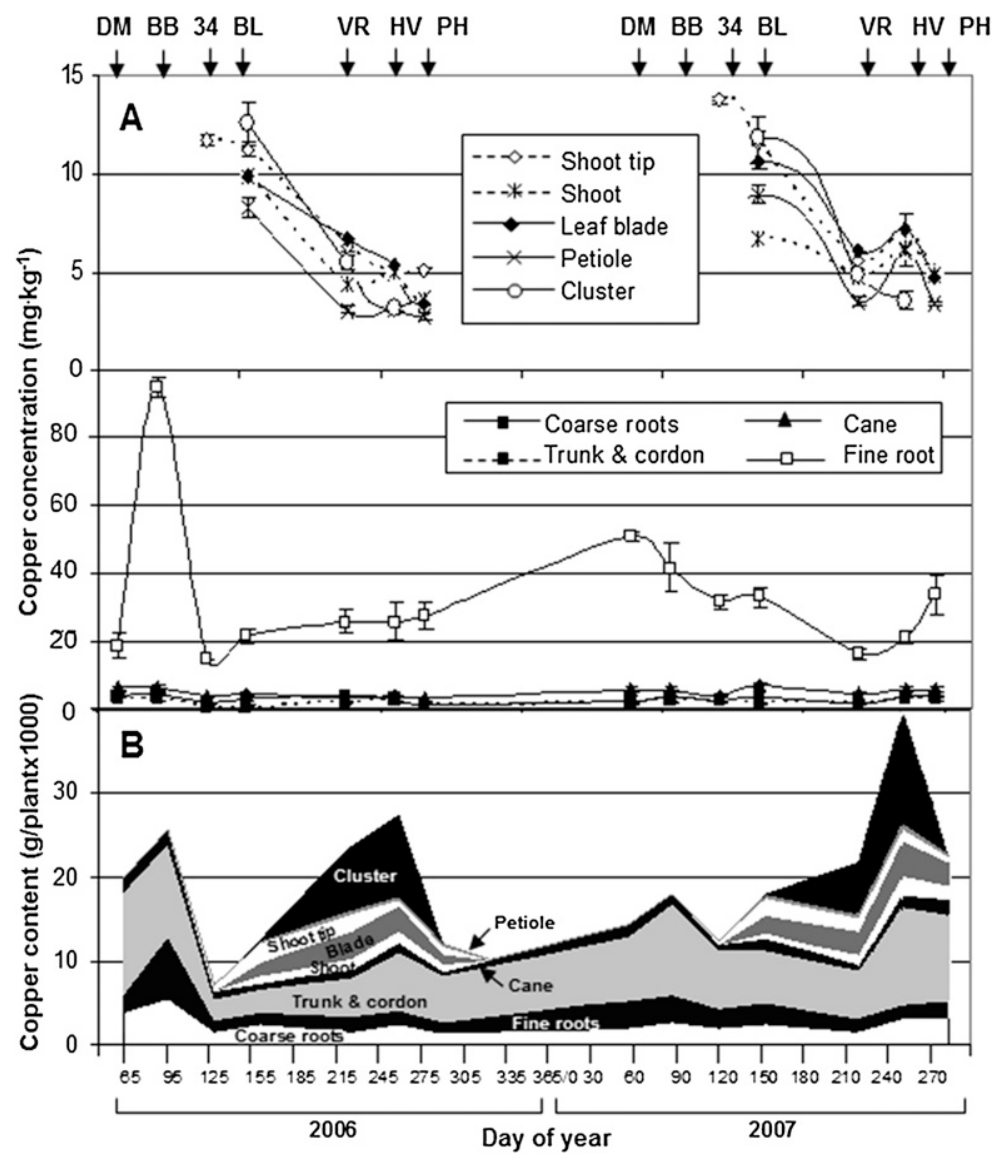

Fig. 5. Seasonal change in concentrations (A) and contents (B) of copper in various organs of 'Concord' grape in 2006 and 2007. Arrows at the top of graph indicate the time of dormant (DM), budbreak (BB), three- to four-leaf stage (34), bloom (BL), veraison (VR), harvest (HV), and postharvest $(\mathrm{PH})$. Data points represent means with SE at each sampling date $(\mathrm{n}=4)$.

fruit maturity ( 85 to $93 \mathrm{mg} / \mathrm{vine}$ ), although there was no consistent pattern of Mn accumulation in vine roots.

During active vine growth, B and $\mathrm{Mn}$ concentrations changed in the annual tissues with different stages of vine physiological development. The highest $\mathrm{B}$ concentration in leaves and clusters occurred at bloom followed by a sharp decrease in cluster B concentration, whereas that of leaf blades, petioles, and shoot tips decreased slightly in later growth stages (Fig. 2). In contrast, Mn concentrations in leaves and cluster drastically increased from the three- to four-leaf stage to harvest (Fig. 4). Hence, during active vine growth, Mn seems to have had a higher accumulation rate in leaves than $B$, whereas a higher proportion of $\mathrm{B}$ was translocated to clusters. However, after harvest, B and Mn content of leaf blades, petioles, and shoot tips remained unchanged until the end of the season, suggesting that they did not migrate from leaves into woody tissues.

Boron is generally recognized as being immobile in the phloem tissues of plants (Marschner, 2002; Zimmermann, 1960). However, in our study, B had moderate phloem mobility in 'Concord' grapevines as evidenced by similar B concentrations in shoot tips and leaf blades with the exception of lower shoot tip B concentration at budbreak in 2006. Furthermore, high B accumulation in clusters suggested that fruit was a strong sink for $\mathrm{B}$. The finding is consistent with Brown and $\mathrm{Hu}$ (1996) who studied B mobility in various plant species. They

supports the finding that $\mathrm{B}$ movement between woody and annual tissues at the beginning of the season was consistent with what happened at the end of season when $B$ was withdrawn from annual to woody tissues. Potentially, the degree of $\mathrm{B}$ translocated out of mature leaves back to woody tissues would depend on the proportion of the $\mathrm{B}$ fraction that is readily mobile versus how much $\mathrm{B}$ is incorporated into the cell wall and thus unavailable (Hu and Brown, 1994).

The lack of a strong correlation between Mn concentration and content (Table 2) was probably the result of high variability in fine root Mn concentration at the beginning of the season in both years as well as leaf blade and petiole Mn concentration postharvest in 2007 (Fig. 4) despite consistent dry weight accumulation over both years (Fig. 1). However, Mn content was significantly different by organ and growth stage each year, suggesting that seasonal changes of $\mathrm{Mn}$ content reflected greater mobilization of $\mathrm{Mn}$ from the canopy in 2006 in comparison with 2007. Specifically, the continuous decrease in $\mathrm{Mn}$ content in the trunk, cordons, and coarse roots from the beginning of the 2007 season until reaching the lowest point at veraison was consistent with continuous increase of Mn content in leaf blades and petioles. The increase in vine Mn content could be attributed to leaf blades with a high Mn content at harvest ( 25 to $30 \mathrm{mg} / \mathrm{vine}$ ). This is consistent with the findings of Schreiner et al. (2006) on 23-year-old 'Pinot Noir', who reported that leaf blades contain the greatest quantity of $\mathrm{Mn}$ at reported that B is phloem-mobile in grape as a result of higher $\mathrm{B}$ concentrations found in apical (younger) than basal (older) leaves and that younger leaves transpired less water than older leaves. Gupta (1979) found that the supply of B needed for reproductive growth in many crops was in excess of the need for vegetative growth found and this is probably because B is an essential micronutrient for pollen germination and pollen tube growth (O'Kelley, 1957).

In addition, Brown and Hu (1996) and Brown and Shelp (1997) reported much higher B concentrations in almond (Prunus dulcis Mill.) and apple (Malus $\times$ domestica Borkh.) fruit organs (hull, kernel, and shell) than fruit organs of pistachio (Pistacia vera $\mathrm{L}$.) and walnut (Juglans regia $\mathrm{L}$.) grown under similar condition of B availability. Brown and Shelp (1997), Hanson (1991), and Picchioni et al. (1995) demonstrated that foliar-applied B readily translocated out of the mature leaves of sorbitol-rich species within the genera Prunus L., Pyrus L., and Malus Mill. Hence, there is an obvious need to study B mobility in economically important perennial fruit to improve the most effective B fertilization methods to correct B deficiency and to optimize crop yield. For example, foliar application of B has not been widely used as a result of the belief that B immobility would limit the effectiveness of the foliar applications (Brown and Shelp, 1997).

Iron, $\mathrm{Cu}$, and $\mathrm{Zn}$ contents varied seasonally as evidenced by variable organ contents (Figs. 3, 5, and 6). The weak correlation 


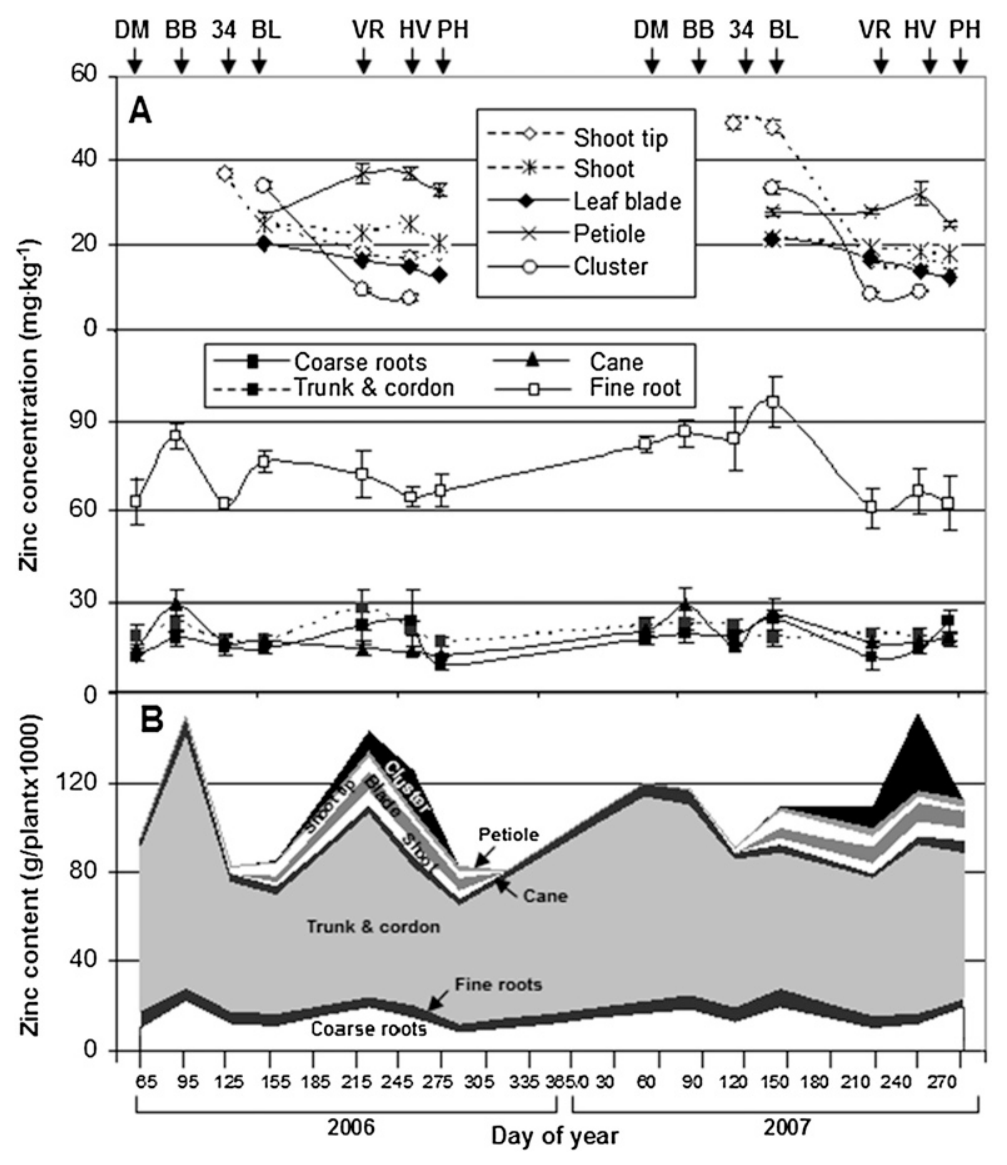

Fig. 6. Seasonal change in concentrations (A) and contents $(\mathbf{B})$ of zinc in various organs of 'Concord' grape in 2006 and 2007. Arrows at the top of graph indicate the time of dormant (DM), budbreak (BB), three- to four-leaf stage (34), bloom (BL), veraison (VR), harvest (HV), and postharvest (PH). Data points represent means with SEs at each sampling date $(n=4)$.

between Fe concentration and content (Table 2) was likely the result of the high concentrations occurring in fine roots and varying concentrations in petioles and shoot tips throughout the two growing seasons (Fig. 3). Compared with other micronutrients in which whole vine contents peaked at harvest, $\mathrm{Fe}$ content in the whole plant was highest at veraison in both years, but the content in 2007 appeared to be higher in woody tissues and clusters and lower in leaf blades and shoot tips than in 2006. In this regard, $\mathrm{Fe}$ concentration in clusters at veraison was higher in 2007, whereas the other tissues were consistent between years. In addition, lower Fe concentration, but higher plant biomass, was observed in clusters at harvest 2007, suggesting a combination effect of concentration and biomass at peak content.

Analysis of nutrient content relative to concentration, plant dry weight, and the interaction between concentration and dry weight showed that $\mathrm{B}$ and $\mathrm{Zn}$ were significantly correlated $(P<$ $0.01)$, whereas $\mathrm{Cu}, \mathrm{Fe}$, and $\mathrm{Mn}$ were not $(P>0.05$; Table 2). Copper content was not related to $\mathrm{Cu}$ concentration overall but $\mathrm{Zn}$ was. In 2006, both $\mathrm{Cu}$ and $\mathrm{Zn}$ content peaked at budbreak, which was associated with high concentrations in the trunk, cordon, and fine roots (Figs. 5 and 6, respectively). Decreased trunk and cordon $\mathrm{Cu}$ and $\mathrm{Zn}$ concentrations occurred when $\mathrm{Cu}$ and $\mathrm{Zn}$ contents were lowest at both the three- to four-leaf stage and bloom. In 2006, Cu content peaked a second time at harvest with a considerable amount of $\mathrm{Cu}$ accumulated in clusters $(35 \%$ of the total), whereas that of $\mathrm{Zn}$ peaked at veraison with highest contents in the trunk and cordon ( $80 \%$ of the total). In $2007, \mathrm{Cu}$ and $\mathrm{Zn}$ content peaked at harvest. Their amounts in clusters increased continuously through to harvest, but those in the trunk and cordon at each growth stage were more consistent than in 2006. In 2007, $\mathrm{Cu}$ and $\mathrm{Zn}$ uptake occurred from veraison to harvest, being $\approx 20$ and $30 \mathrm{mg} /$ vine, respectively.

SoIL NUTRIENTS. In both growing seasons, soil nutrient availability did not show clear seasonal trends. However, with the exception of $\mathrm{Ca}$, nutrient concentrations in the surface soil were significantly higher than in the subsurface soil (Table 3 ). This is consistent with the finding of Schreiner (2005) on Oregon 'Pinot Noir' study, who reported that the site subsoil contains significantly higher $\mathrm{Mg}$ concentrations than the topsoil.

Microsite differences in soil $\mathrm{pH}$ likely contribute to variable nutrient availability around the root system, which could explain the high variability of $\mathrm{Fe}, \mathrm{Cu}$, and $\mathrm{Zn}$ content in fine roots. Bulk soil sampling and extraction processes would not capture this variability. In addition, nutrient status of perennial tissues is a combination of remobilization and uptake. It is also possible that the soil extractions overestimated plant-available nutrients and therefore did not show a relationship with vine nutrient status.

Changes in the soil environment often have a greater effect on micronutrient rather than the macronutrient nutritional status of plants (Moraghan and Mascagni, 1991). Soil climatic conditions such as high moisture and low temperature can greatly affect the productivity of 'Concord' grape grown in calcareous soil (Davenport and Steven, 2006). In particular, the development of grape chlorosis has been shown to be associated with high levels of available soil $\mathrm{Ca}$ and $\mathrm{Mg}$ as well as low levels of Fe and Mn (Davenport and Steven, 2006). Understanding of nutrient partitioning and balances in 'Concord' grape may be further elucidated by research into the relationship between soil and vine nutrient status, nutrient-nutrient interactions, $\mathrm{pH}$ adjustment in calcareous vineyard soils, and soil physical properties affecting mineral nutrient availability, movement, and uptake in grapevines (Cass, 2005).

\section{Conclusions}

Seasonal patterns of micronutrient concentrations varied considerably as to in which organ and growth stage that attained the highest concentration. Leaf blades, shoot tips, and petioles showed the highest concentrations of $\mathrm{B}$ at bloom and showed the highest concentration of $\mathrm{Mn}$ at harvest, whereas fine roots had the highest concentration of $\mathrm{Fe}, \mathrm{Cu}$, and $\mathrm{Zn}$, although values varied with sampling time each year.

Allocation of absorbed and stored nutrients takes place based on nutrient mobility and relative organ nutrient demand. During the two growing seasons, almost half of the vine $\mathrm{B}, \mathrm{Fe}$, $\mathrm{Mn}$, and $\mathrm{Cu}$ content was found in leaf blades and clusters from 
Table 3. Average soil available calcium, boron, iron, manganese, copper, and zinc in both surface and subsurface soil at different growth stages of 'Concord' grape in 2006 and 2007.

\begin{tabular}{|c|c|c|c|c|c|c|c|c|c|}
\hline$\underline{\mathrm{Yr}}$ & Growth stage & $\begin{array}{c}\text { Soil depth } \\
(\mathrm{cm})\end{array}$ & Soil $\mathrm{pH}$ & $\begin{array}{c}\text { Calcium } \\
\left(\mathrm{cmol} \cdot \mathrm{kg}^{-1}\right)\end{array}$ & $\begin{array}{c}\text { Boron } \\
\left(\mathrm{mg} \cdot \mathrm{kg}^{-1}\right)\end{array}$ & $\begin{array}{c}\text { Iron } \\
\left(\mathrm{mg} \cdot \mathrm{kg}^{-1}\right)\end{array}$ & $\begin{array}{c}\text { Manganese } \\
\left(\mathrm{mg} \cdot \mathrm{kg}^{-1}\right)\end{array}$ & $\begin{array}{c}\text { Copper } \\
\left(\mathrm{mg} \cdot \mathrm{kg}^{-1}\right)\end{array}$ & $\begin{array}{c}\text { Zinc } \\
\left(\mathrm{mg} \cdot \mathrm{kg}^{-1}\right)\end{array}$ \\
\hline$\overline{2006}$ & Budbreak & $0-30$ & 7.8 & 22.33 & 0.78 & 36.50 & 34.75 & 2.72 & 6.91 \\
\hline & & $30-75$ & 8.4 & 27.27 & 0.43 & 32.75 & 15.75 & 2.12 & 0.79 \\
\hline & & $30-75$ & 8.3 & 28.03 & 0.56 & 29.25 & 19.00 & 2.36 & 1.60 \\
\hline & Bloom & $0-30$ & 7.7 & 24.17 & 0.68 & 32.25 & 29.75 & 2.67 & 7.06 \\
\hline & & $30-75$ & 8.2 & 26.42 & 0.46 & 33.50 & 21.00 & 2.51 & 3.04 \\
\hline & Harvest & $0-30$ & 7.7 & 23.52 & 0.0 .63 & 32.00 & 34.25 & 2.50 & 4.55 \\
\hline & & $30-75$ & 8.3 & 26.71 & 0.48 & 29.00 & 22.25 & 2.09 & 1.70 \\
\hline & Postharvest & $0-30$ & 7.8 & 21.91 & 0.65 & 30.00 & 40.75 & 2.49 & 6.46 \\
\hline & & $30-75$ & 8.2 & 25.22 & 0.58 & 29.25 & 21.00 & 2.06 & 3.10 \\
\hline & $P$ value by soil depth & & & $<0.0001$ & $<0.0001$ & $<0.0001$ & $<0.0001$ & $<0.0001$ & $<0.0001$ \\
\hline & & $30-75$ & 8.4 & 44.65 & 0.46 & 28.50 & 21.75 & 2.54 & 2.64 \\
\hline & Bloom & $0-30$ & 7.7 & 33.39 & 0.62 & 42.00 & 52.75 & 3.08 & 8.86 \\
\hline & & $30-75$ & 8.1 & 39.31 & 0.56 & 34.50 & 32.75 & 2.58 & 4.90 \\
\hline & Veraison & $0-30$ & 7.6 & 30.54 & 0.70 & 43.50 & 56.75 & 2.77 & 6.20 \\
\hline & & $30-75$ & 8.2 & 41.75 & 0.47 & 30.25 & 23.25 & 2.45 & 1.42 \\
\hline & Harvest & $0-30$ & 7.6 & 32.08 & 0.66 & 38.00 & 48.25 & 2.75 & 7.03 \\
\hline & & $30-75$ & 8.2 & 39.60 & 0.34 & 32.00 & 19.25 & 1.87 & 0.95 \\
\hline & Postharvest & $0-30$ & 7.8 & 33.46 & 0.79 & 39.50 & 40.50 & 2.87 & 5.71 \\
\hline & & $30-75$ & 8.4 & 45.63 & 0.41 & 27.50 & 15.00 & 2.36 & 1.05 \\
\hline & $P$ value by soil depth & & & $<0.0001$ & $<0.0001$ & $<0.0001$ & $<0.0001$ & $<0.0001$ & $<0.0001$ \\
\hline
\end{tabular}

veraison to harvest, whereas up to $77 \%$ of $\mathrm{Zn}$ was in the trunk and cordon and $\approx 15 \%$ of $\mathrm{Fe}$ and $\mathrm{Cu}$ in fine roots throughout the growing seasons. Seasonal dynamics of B and Mn content shared a common pattern. There was a translocation of the nutrients from woody tissues to actively growing organs early in the season. However, the majority of B uptake (53\% to $90 \%$ of total) occurred from bloom to veraison, whereas Mn uptake (76\% to $95 \%$ of total) continued until harvest. Thus, annual tissue demand was clearly the driver for nutrient uptake for these two elements. This is nicely depicted by the total annual uptake, in which the average per plant in 2006 were $59 \mathrm{mg} \mathrm{B}$ and $64 \mathrm{mg} \mathrm{Mn}$ in 2006, yet there was an overall higher uptake in 2007 (73 mg B and $92 \mathrm{mg} \mathrm{Mn}$ ), which corresponded to a higher cluster biomass in the 2007.

Translocation of $\mathrm{B}$ back to woody tissues began after veraison and ended by leaf senescence. In addition, B movement between woody and annual tissues at the beginning of the season was consistent with what happened at the end of season when B moved into the coarse roots postharvest. The presence of fruit as a strong sink of B and moderate phloem mobility of $\mathrm{B}$ in 'Concord' grapevines suggest further study of B mobility in perennial plants to improve B fertilization and deficiency diagnosis methods.

Seasonal changes in $\mathrm{Fe}, \mathrm{Cu}$, and $\mathrm{Zn}$ content were variable between years. Unlike B and $\mathrm{Mn}$, these micronutrients were primarily in woody tissues, indicating an important structural role in 'Concord' grape.

\section{Literature Cited}

Anderson, P.R. and T.H. Christensen. 1988. Distribution coefficients of $\mathrm{Cd}, \mathrm{Co}, \mathrm{Ni}$, and $\mathrm{Zn}$ in soils. J. Soil Sci. 39:15-22.

Bates, T., R. Dunst, T. Taft, and M. Vercant. 2002. The vegetative response of 'Concord' grapevines to soil $\mathrm{pH}$. HortScience 37:890893.

Borchert, R. 1976. The concept of juvenility in woody plants. Acta Hort. 56:21-33.

Brady, N.C. and R. Weil. 1999. The nature and properties of soil. 12th Ed. MacMillan, New York, NY.

Brown, P.H. and H. Hu. 1996. Phloem mobility of boron is species dependent: Evidence for phloem mobility in sorbitol-rich species. Ann. Bot. (Lond.) 77:497-505.

Brown, P.H. and B.J. Shelp. 1997. Boron mobility in plants. Plant Soil 193:85-101.

Cass, A. 2005. Effects of soil physical characteristics on mineral nutrient availability, movement, and uptake, p. 3-11. In: Christensen, P. and D.R. Smart (eds.). Proc. Symp. on Soil Environment and Vine Mineral Nutrition, San Diego, CA29-30 June 2004. Amer. Soc. Enol. Viticult., Davis, CA.

Chesworth, W. 1991. Geochemistry of micronutrients, p. 1-30. In: Mortvedt, J.J., F.R. Cox, L.M. Shuman, and R.M. Welch (eds.). Micronutrients in agriculture. 2nd Ed. Soil Sci. Soc. Amer., Madison, WI.

Colugnati, G., R. Camerlynck, L. Kiekens, and P. Bekaert. 1995. Contents patterns of $\mathrm{Fe}, \mathrm{Mn}$ and B in four grapevine cultivars. Acta Hort. 383:273-277.

Conradie, W.J. 1980. Seasonal uptake of nutrients by Chenin Blanc in sand culture: I. Nitrogen. South African J. Enol. Viticult. 1:59-65. 
Conradie, W.J. 2005. Partitioning of mineral nutrients and timing of fertilizer application for optimum efficiency, p. 69-81. In: Christensen, P. and D.R. Smart (eds.). Proc. Symp. on Soil Environment and Vine Mineral Nutrition, San Diego, CA. 29-30 June 2004. Amer. Soc. Enol. Viticult., Davis, CA.

Daniels, L.W. and K.C. Haering. 2006. Concepts of basic soil science, p. 33-52. In: Haering, K.C. and G.K. Evanylo (eds.). Mid-Atlantic nutrient management handbook. MAWQP 06-02. Mid-Atlantic Regional Water Project, College Park, MD.

Davenport, J.R. and R.G. Steven. 2006. High soil moisture and low soil temperature are associated with chlorosis occurrence in 'Concord' grape. HortScience 41:418-422.

Epstein, E. and A.J. Bloom. 2005. Mineral nutrition of plants: Principles and perspectives. 2nd Ed. Sinauer, Sunderland, MA.

Gupta, U.C. 1979. Boron nutrition of crops. Adv. Agron. 31:273-307.

Hanson, E.J. 1991. Movement of boron out of tree fruit leaves. HortScience 26:271-273.

$\mathrm{Hu}, \mathrm{H}$. and P.H. Brown. 1994. Localization of boron in cell walls of squash and tobacco and its association with pectin. Plant Physiol. 105: 681-689.

Iyengar, S.S., D.C. Martens, and W.P. Miller. 1981. Distribution and plant availability of soil zinc fractions. Soil Sci. Soc. Amer. J. 45: 735-739.

Loganathan, P., R.G. Burau, and D.W. Fuerstenau. 1977. Influence of $\mathrm{pH}$ on $\mathrm{Co}^{2+}, \mathrm{Zn}^{2+}$ and $\mathrm{Ca}^{2+}$ by a hydrous manganese oxide. Soil Sci. Soc. Amer. J. 41:57-62.

Marschner, H. 2002. Mineral nutrition of higher plants. 2nd Ed. Academic Press, New York, NY.

Mehlich, A. 1984. Mehlich-3 soil test extractant: A modification of Mehlich-2 extractant. Commun. Soil Sci. Plant Anal. 15:1409-1416. Melton, J.R., S.K. Mathab, and A.R. Swoboda. 1973. Diffusion of zinc in soils as a function of applied zinc, phosphorus, and soil $\mathrm{pH}$. Soil Sci. Soc. Amer. Proc. 37:379-381.

Moraghan, J.T. and H.J. Mascagni, Jr. 1991. Environmental and soil factors affecting micronutrient deficiencies and toxicities, p. 371425. In: Mortvedt, J.J., F.R. Cox, L.M. Shuman, and R.M. Welch (eds.). Micronutrients in agriculture. 2nd Ed. Soil Sci. Soc. Amer., Madison, WI.

Morlat, R. and A. Jacquet. 1993. The soil effects on the grapevine root system in several vineyards of the Loire Valley (France). Vitis 32:35-42.

Mulllins, M.G., A. Bouquet, and L.E. Williams. 1992. Biology of the grapevine. Cambridge University Press, Cambridge, UK.

O'Kelley, J.C. 1957. Boron effects on growth, oxygen uptake, and sugar absorption by germinating pollen. Amer. J. Bot. 44: 239-244.

Picchioni, G.A., S.A. Weinbaum, and P.H. Brown. 1995. Retention and the kinetics of uptake and export of foliage-applied, labeled boron by apple, pear, prune, and sweet cherry leaves. J. Amer. Soc. Hort. Sci. 120:28-35.
Pradubsuk, S. and J.R. Davenport. 2010. Seasonal uptake and partitioning of macronutrients in mature 'Concord' grape. J. Amer. Soc. Hort. Sci. 135:474-483.

Robinson, J.B. 2005. Critical plant tissue values and application of nutritional standards for practical use in vineyards, p. 61-68. In: Christensen, P. and D.R. Smart (eds.). Proc. Symp. on Soil Environment and Vine Mineral Nutrition, San Diego, CA. 29-30 June 2004. Amer. Soc. Enol. Viticult., Davis, CA.

Schreiner, R.P. 2005. Spatial and temporal variation of roots, arbuscular mycorrhizal fungi, and plant and soil nutrients in a mature 'Pinot Noir' (Vitis vinifera L.) vineyard in Oregon, USA. Plant Soil 276:219-234.

Schreiner, R.P. and R.G. Linderman. 2005. Mycorrhizal colonization in dryland vineyards of the Willamette Valley, Oregon. Small Fruits Rev. 4:41-55.

Schreiner, R.P., C.F. Scagel, and J. Baham. 2006. Nutrient uptake and distribution in a mature 'Pinot Noir' vineyard. HortScience 41:336345 .

Shuman, L.M. 1998. Micronutrient fertilizers. J. Crop Prod. 1:165195.

Sims, J.T. 1986. Soil pH effects on the distribution and plant availability of manganese, copper and zinc. Soil Sci. Soc. Amer. J. 50:367-373.

Sinclair, A.H., L.A. Mackie-Dawson, and D.L. Linehan. 1990. Micronutrients inflow rates and mobilization into soil solution in the root zone of winter wheat (Triticum aestivum L.). Plant Soil 122:143-146.

Smart, D.R., E. Schwass, A.N. Lakso, and L. Morano. 2005. Grapevine rooting patterns: A comprehensive analysis and review, p. 153-174. In: Christensen, P. and D.R. Smart (eds.). Proc. Symp. on Soil Environment and Vine Mineral Nutrition, San Diego, CA. 29-30 June 2004. Amer. Soc. Enol. Viticult., Davis, CA.

Smart, R.E. and B.G. Coombe. 1983. Water relation of grapevines, p. 137-196. In: Kozlowski, T.T. (ed.). Water deficit and plant growth. Vol. III. Academic Press, New York, NY.

Soltanpour, P.N., G.W. Johnson, S.M. Workman, J.B. Jones, Jr., and R.O. Miller. 1996. Inductively coupled plasma emission spectrometry and inductively coupled plasma-mass spectrometry, p. 91-139. In: Sparks, D.L. (ed.). Methods of soil analysis. Part 3. Soil Sci. Soc. Amer., Madison, WI.

Tiffin, L.O. 1972. Translocation of micronutrients in plants, p. 199224. In: Mortvedt, J.J., P.M. Giordano, and W.L. Lindsay (eds.). Micronutrients in agriculture. Soil Sci. Soc. Amer., Madison, WI.

Tinker, P.B. and P.H. Nye. 2000. Solute movement in the rhizosphere. Oxford University Press, Oxford, UK/New York, NY.

U.S. Department of Agriculture. 2008. Non-citrus fruits and nuts 2007 preliminary summary. 23 Jan. 2009. <http://usda.mannlib.cornel1.edu/usda/nass/SB985/sb1011.pdf/>.

Winkler, A.J., J.A. Cook, W.M. Kliewer, and L.A. Lider. 1974. General viticulture. Univ. of Californa, Berkeley, CA.

Zimmermann, M.H. 1960. Transport in the phloem. Annu. Rev. Plant Physiol. 11:167-190. 